\title{
MINIMUM INHIBITORY CONCENTRATION (MIC) OF LIQUID SMOKE PRODUCED FROM PIPER BETLE L AGAINST SALMONELLA SP AND STAPHYLOCOCCUS AUREUS
}

\author{
Dodi Irwandi, Ai Emalia Sukmawati \\ Jurusan Analisis Farmasi dan Makanan, Poltekkes Kemenkes Jakarta 2 \\ Jl. Raya Ragunan No 29C. Pasar Minggu Jakarta Selatan, 12540 \\ E-mail: ddi irwandi81@yahoo.com
}

Submitted: $1^{\text {st }}$ May 2020; Accepted: $16^{\text {th }}$ June 2020

https://doi.org/10.36525/sanitas.2020.8

\begin{abstract}
The betel (Piper betle L) is an herb that has one of the properties, namely as an antibacterial. Several studies have shown green betel leaf extract can inhibit the growth of Gram-positive and Gram negative bacteria. In this study, the antibacterial activity of liquid smoke produced from betel leaf by pyrolysis using a simple pyrolysis reactor was tested. Tests are carried out on 2 types of liquid smoke namely grade 3 which is the first product of the pyrolysis process and grade 2 which is the result of distillation from grade 3 . Both types of liquid smoke are prepared into concentration of $100 \%, 75 \%, 50 \%, 25 \%$ respectively water as a solvent. Two types of bacteria are used, namely Salmonella sp as Gram-negative bacteria and Staphylococcus aureus as Gram-positive. The test results show that grade 3 and grade 2 liquid smoke give minimum inhibitory concentration (MIC) at the same concentration of 50\% against Salmonella sp and, Staphylococcus aureus at $25 \%, 75 \%$ concentrations, respectively.
\end{abstract}

Keywords: Piper betle L, liquid smoke, antibacterial

This is an open access journal, and articles are distributed under the terms of the Creative Commons Attribution-Non Commercial-Share Alike 4.0 License, which allows others to remix, tweak, and build upon the work non-commercially, as long as appropriate credit is given and the new creations are licensed under the identical terms.

C2020 Sanitas 


\title{
KONSENTRASI HAMBAT MINIMUM (KHM) ASAP CAIR DAUN SIRIH HIJAU (PIPER BETLE L) TERHADAP SALMONELLA SP DAN STAPHYLOCOCCUS AUREUS
}

\begin{abstract}
ABSTRAK
Sirih hijau (Piper betle L) merupakan herbal yang memiliki salah satu khasiat yaitu sebagai antibakteri. Beberapa penelitian menunjukkan ekstrak daun sirih hijau mampu menghambat pertumbuhan bakteri Gram positif dan Gram negatif. Pada penelitian ini dilakukan pengujian aktivitas antibakteri daun sirih hijau yang telah dibuat menjadi asap cair dengan cara pirolis menggunakan reaktor pirolisis sederhana. Pengujian dilakukan terhadap 2 jenis asap cair yaitu grade 3 yang merupakan produk pertama dari proses pirolisis dan grade 2 yang merupakan hasil destilasi dari grade 3. Kedua jenis asap cair tersebut dipreparasi menjadi masing-masing konsentrasi :100\%, 75\%, 50\% dan 25\% menggunakan air sebagai pelarut. Digunakan 2 jenis bakteri yaitu Salmonella sp sebagai bakteri Gram negatif dan Staphylococcus aureus sebagai Gram positif. Hasil pengujian menunjukkan asap cair grade 3 dan grade 2 memberikan konsentrasi hambat minimum (KHM) masing-masing pada konsentrasi yang sama yaitu 50\% terhadap Salmonella sp dan terhadap Staphylococcus aureus masing-masing pada konsentrasi $25 \%$ dan $75 \%$.
\end{abstract}

Kata Kunci: Piper betle L, asap cair, antibakteri

\section{PENDAHULUAN}

Indonesia merupakan negara yang memiliki sumber daya alam hayati yang besar. Bahkan sekitar $80 \%$ tanaman berkhasiat obat di dunia tumbuh dengan baik di wilayah Indonesia (1). Tumbuh suburnya tanaman berkhasiat obat di Indonesia didukung oleh iklim tropis dimana matahari sebagai sumber energi utama bagi tumbuhan tersedia dengan intensitas yang teratur serta curah hujan yang mencukupi sepanjang tahun.

Salah satu tanaman berkhasiat obat yang hidup di Indonesia dan telah secara turun temurun digunakan oleh masyarakat adalah daun sirih hijau (Piper betle L). Tanaman ini memiliki banyak khasiat yang salah satunya adalah sebagai antibakteri sehingga banyak digunakan oleh masyarakat sebagai obat kumur (2).

Penelitian-penelitian mengenai aktivitas antibakteri ekstrak daun sirih hijau telah banyak dilakukan. Ekstrak daun sirih terbukti memiliki kemampuan menghambat pertumbuhan bakteri patogen (3), Streptococcus mutans (4), Staphylococcus epidermidis (5), Escherichia coli (6) dan Staphylococcus aureus (7).

Berbeda dengan penelitian-penelitian tersebut yang mana daun sirih diekstrak dengan pelarut tertentu sehingga dihasilkan ekstrak lalu ekstrak yang diperoleh diuji aktivitas antibakterinya. Penelitian yang penulis lakukan daun sirih diproduksi menjadi asap cair kemudian asap cair tersebut diuji aktivitas antibakterinya. Asap cair diperoleh dengan cara pirolisis yaitu pemanasan dengan sedikit atau tanpa oksigen dalam suatu 
reaktor pirolisis yang dilengkapi dengan kondensor, pada kondisi panas inilah komponenkomponen volatile dari daun sirih menguap dan terkondensasi menghasilkan cairan yang dikenal dengan asap cair. Produk asap cair yang diperoleh dari tahap pertama pirolisis disebut asap cair grade 3, kemudian setelah dimurnikan dari senyawa tar dengan cara destilasi satu kali disebut asap cair grade 2. Tujuan dari penelitian ini adalah untuk mendapatkan nilai Konsentrasi Hambat Minimum (KHM) asap cair daun hijau grade 3 dan grade 2 terhadap bakteri Staphylococcus aureus dan Salmonella sp.

\section{METODE PENELITIAN}

\section{Alat dan Bahan}

Alat yang digunakan adalah Spektrofotometer UV-Vis, timbangan analitik, inkubator, vortex, jangka sorong, laminar air flow, heating mantle, autoklaf, satu set alat destilasi serta peralatan gelas.

Bahan yang digunakan yaitu Asap cair grade 3 dan grade 2, bakteri Salmonella sp dan Staphylococcus aureus. $\mathrm{NaCl}$ 0,9\%, Cakram Chloramphenicol 1000 ppm, Cakram Tetrasiklin 1000 ppm, media trypticase soy agar (TSA) dan aquadest steril.

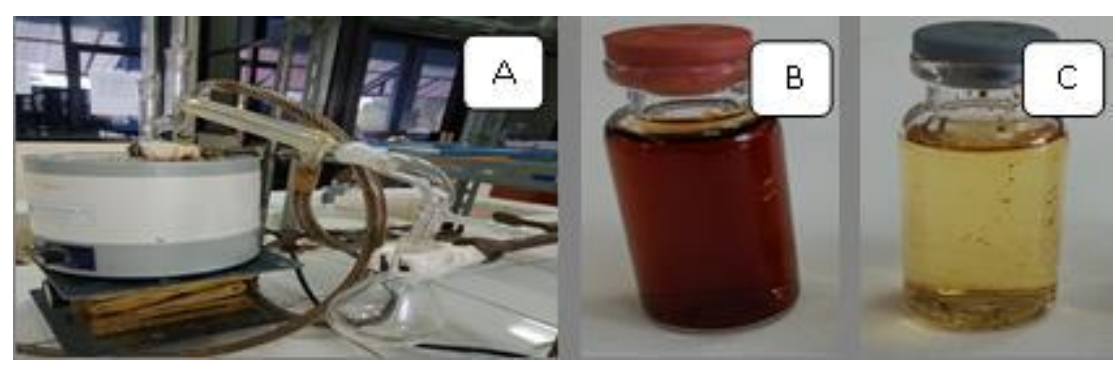

Gambar 1 A) Seperangkat alat destilasi; B) Asap cair grade 3; C) Asap cair grade 2

\section{Pembuatan Asap Cair Grade 2}

Asap cair grade 2 dibuat dengan cara dilakukan destilasi terhadap asap cair grade 3 sebanyak satu kali pada suhu $90{ }^{\circ} \mathrm{C}$.

\section{Pembuatan Larutan Uji}

Asap cair grade 3 dan grade 2 disiapkan menjadi 4 konsentrasi yaitu 100\%, 75\%, $50 \%$ dan 25\% menggunakan aquadest steril sebagai pelarut. 


\section{Persiapan Kultur Bakteri}

Persiapan kultur bakteri uji Salmonella sp dan Staphylococcus aureus: bakteri diinokulasikan ke media TSA, kemudian diinkubasi pada suhu $30-35^{0} \mathrm{C}$ selama 24 jam. Bakteri yang tumbuh diencerkan dengan $\mathrm{NaCl}$ 0,9\%, dan kekeruhannya disesuaikan dengan Mc Farland 0,5 (1,5 x $108 \mathrm{cfu} / \mathrm{mL})$.

Tabel 1 Zona Hambat Asap Cair grade 3 terhadap Bakteri Salmonella sp

\begin{tabular}{lrrr}
\hline Konsentrasi & \multicolumn{3}{c}{ Diameter Daya Hambat (mm) } \\
& Ulangan 1 & Ulangan 2 & Ulangan 3 \\
\hline $100 \%$ & 13,3 & 14,4 & 20,1 \\
$75 \%$ & - & 8,4 & 12,4 \\
$50 \%$ & - & 6,7 & 9,7 \\
$25 \%$ & 6 & 6 & 6 \\
K+ ( Chloramphenicol $1000 \mathrm{ppm})$ & 18,5 & 19,8 & - \\
K- (air) & 6 & 6 & 6 \\
\hline
\end{tabular}

Ket. K+ : Kontrol posifit, K- : Kontrol negatif

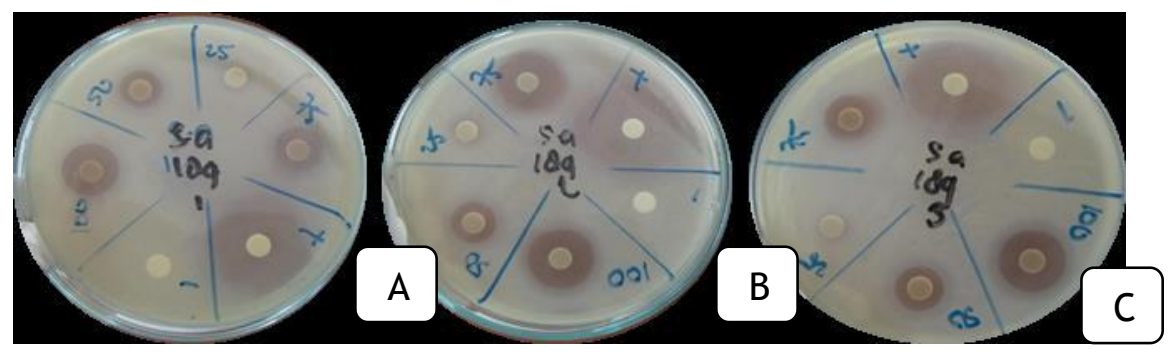

Gambar 2 Daya hambat asap cair grade 3 terhadap Salmonella sp

A) ulangan ke-1; B) ulangan ke-2; C) ulangan ke-3

\section{Persiapan Media Uji}

Sebanyak 0,2 $\mathrm{mL}$ inokulum Salmonella sp dan Staphylococcus aureus yang jumlahnya setara dengan Mc Farland 0,5 diinokulasikan masing-masing ke dalam $20 \mathrm{~mL}$ media TSA kemudian dihomogenkan. Media TSA yang telah mengandung bakteri uji dituang ke dalam cawan petri steril dan dibiarkan mengeras.

\section{Persiapan cakram kertas}

Dicelupkan cakram kertas masing-masing ke dalam larutan uji, kontrol negatif (aquadest steril). Untuk kontrol positif digunakan cakram kertas komersial yang telah mengandung antibiotik yaitu cakram Chloramphenicol 1000 ppm untuk uji antibakteri 
Salmonella sp dan cakram Tetrasiklin 1000 ppm untuk uji antibakteri Staphylococcus aureus.

Tabel 2 Zona Hambat Asap Cair grade 3 terhadap Bakteri Staphylococcus aureus

\begin{tabular}{lccc}
\hline Konsentrasi & \multicolumn{3}{c}{ Diameter Daya Hambat (mm) } \\
& Ulangan 1 & Ulangan 2 & Ulangan 3 \\
\hline $100 \%$ & 15,2 & 18,3 & 17,3 \\
$75 \%$ & 13,7 & 19,5 & 14,5 \\
$50 \%$ & 11,3 & 12,3 & 11,8 \\
$25 \%$ & 9,7 & 8,6 & 8,5 \\
K+ ( Tetrasiklin 1000 ppm) & 28,6 & 30,1 & 31,5 \\
K- (air) & 6 & 6 & 6 \\
\hline
\end{tabular}

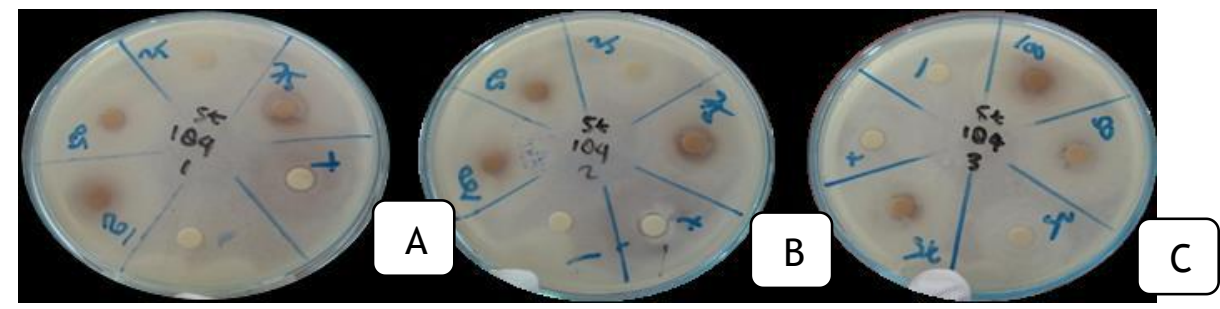

Gambar 3 Daya hambat asap cair grade 3 terhadap Staphylococcus aureus

A) ulangan ke-1; B) ulangan ke-2; C) ulangan ke-3

\section{Tahap Pengujian}

Cakram kertas yang sudah disiapkan ditempatkan pada masing-masing media uji, didiamkan selama 1 jam selanjutnya diinkubasi pada suhu $30-35^{0} \mathrm{C}$ selama 24 jam. Pengamatan dilakukan dengan mengukur zona penghambatan yang ditandai dengan area bening di sekeliling cakram. Pengukuran dilakukan dalam satuan milimeter (mm). Pengulangan dilakukan sebanyak 3 (tiga) kali.

\section{HASIL DAN PEMBAHASAN}

Pirolisis merupakan teknik pemanasan yang dilakukan dalam keadaan minim atau tanpa oksigen. Salah satu zat berbahaya yang akan dihasilkan dari proses pirolisis adalah tar (8). Tar merupakan senyawa kimia yang memiliki potensi sebagai karsinogenik. Untuk menghilangkan kandungan tar dalam asap cair grade 3 yang merupakan produk pertama dari pirolisis yaitu dengan dilakukan destilasi (Gambar 1A) (9). Destilasi 
dilakukan pada suhu $90^{\circ} \mathrm{C}$, destilat yang tertampung di labu penampung disebut sebagai asap cair grade 2 .

Tabel 3 Zona hambat asap cair grade 2 terhadap bakteri Salmonella sp

\begin{tabular}{lccc}
\hline Konsentrasi & \multicolumn{3}{c}{ Diameter Daya Hambat (mm) } \\
& Ulangan 1 & Ulangan 2 & Ulangan 3 \\
\hline $100 \%$ & 13.3 & 14.4 & 20.1 \\
$75 \%$ & - & 8.4 & 12.4 \\
$50 \%$ & - & 6.7 & 9.7 \\
$25 \%$ & 6 & 6 & 6 \\
K+ (Chloramphenicol 1000 ppm) & 18.5 & 19.8 & - \\
K- (air) & 6 & 6 & 6 \\
\hline
\end{tabular}

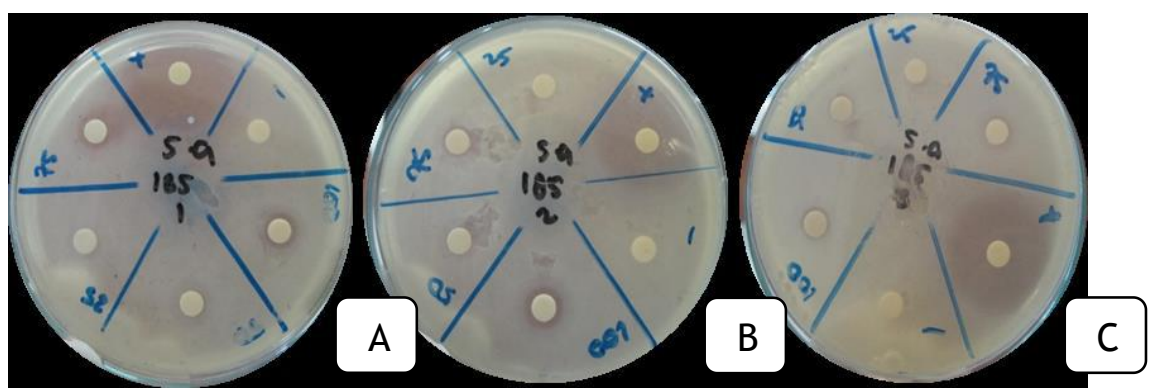

Gambar 4 Daya hambat asap cair grade 2 terhadap Salmonella $\mathrm{sp}$

A) ulangan ke-1; B) ulangan ke-2; C) ulangan ke-3

Asap cair daun sirih hijau grade 3 memiliki warna yang lebih pekat dibandingkan dengan grade 2 (Gambar 1A dan 1B), hal ini disebabkan kandungan fenolnya yang lebih tinggi dibandingkan grade 2. Berdasarkan penelitian yang telah dilakukan kandungan fenol total asap cair grade 3 yaitu 14,77 mg/g dan 0,004 mg/g untuk grade 2 (10).

Penelitian antibakteri digunakan bakteri Salmonella sp sebagai representasi dari bakteri Gram negatif dan Staphylococcus aureus sebagai bakteri Gram positif. Penelitian dengan menggunakan 2 jenis bakteri ini belum bisa memberikan kesimpulan bahwa zat memiliki antibakteri spektrum luas, maka perlu dilakukan penelitian lebih lanjut. Hasil penelitian yang dapat dilaporkan yaitu konsentrasi hambat minimal terhadap kedua jenis bakteri uji.

Konsentrasi hambat minimal asap cair grade 3 terhadap Salmonella sp yaitu sebesar $50 \%$ begitupun asap cair grade 2 (Gambar 2 dan 5, Tabel 1 dan 3). Terhadap bakteri Staphylococcus aureus asap cair grade 3 memiliki konsentrasi hambat minimal yaitu 
sebesar 25\% sedangkan grade 2 75\% (Gambar 3 dan 6, Tabel 2 dan 4). Diduga bahwa kandungan fenol dalam asap cair grade 3 yang lebih tinggi dibandingkan grade 2 memberikan kemampuan daya hambat yang berbeda terhadap bakteri Gram positif yang memiliki lapisan peptidoglikan yang lebih tebal pada dinding selnya dibandingkan Gram negatif.

Tabel 4 Zona hambat asap cair grade 2 terhadap bakteri Staphylococcus aureus

\begin{tabular}{lccc}
\hline Konsentrasi & \multicolumn{3}{c}{ Diameter Daya Hambat (mm) } \\
& Ulangan 1 & Ulangan 2 & Ulangan 3 \\
\hline $100 \%$ & 9.4 & 9.8 & 8.4 \\
$75 \%$ & 8.6 & 7.9 & - \\
$50 \%$ & 6 & 6 & 6 \\
$25 \%$ & 6 & 6 & 6 \\
K+ (Chloramphenicol 1000 ppm) & 6 & 6 & 6 \\
K- (air) & 6 & 6 & 6 \\
\hline
\end{tabular}

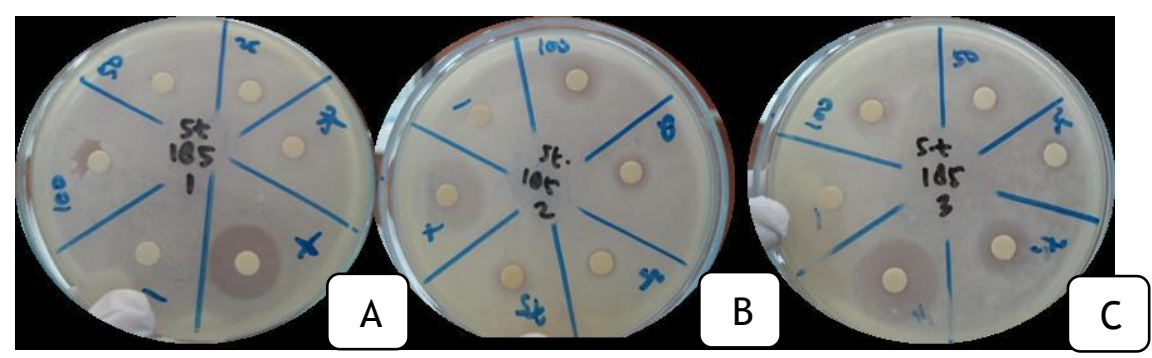

Gambar 5 Daya hambat asap cair grade 3 terhadap Staphylococcus aureus A) ulangan ke-1; B) ulangan ke-2; C) ulangan ke-3

Bakteri Gram negatif memiliki lapisan peptidoglikan yang lebih tipis tetapi memiliki tambahan lapisan luar pada membrannya, kedua jenis asap cair ini cenderung memiliki daya hambat yang sama, belum bisa dipastikan penyebabnya, namun diduga zat-zat yang terkandung di dalam kedua jenis asap cair memiliki peran yang sinergis terhadap daya hambatnya. Penelitian ini belum bisa menjawab zat-zat sinergis yang terkandung di dalamnya, perlu penelitian lebih lanjut dalam hal uji aktivitas antibakteri menggunakan fraksi-fraksi yang terkandung dalam kedua jenis asap cair. Sebagaimana yang telah dilaporkan bahwa dalam asap cair daun sirih hijau grade 3 mengandung senyawa Isamoxole, 5,10-Diethoxy-2,3,7,8-tetrahydro-1H,6H-dipyrrolo[1,2-a;1',2'-d]pyrazine dan 3,5-Dimethoxyphenol (11) dan secara umum dalam asap cair komersial terdapat tiga senyawa utama yaitu asam organik, fenol, dan turunan dari fenol (12). Senyawa-senyawa 
tersebut diduga memiliki efek sinergis terhadap kemampuan dalam menghambat pertumbuhan bakteri.

\section{SIMPULAN}

Asap cair grade 3 dan grade 2 memiliki konsentrasi hambat minimum (KHM) terhadap Salmonella sp yaitu sebesar 50\% dan terhadap Staphylococcus aureus masingmasing $25 \%$ dan $75 \%$.

\section{UCAPAN TERIMA KASIH}

Penulis mengucapkan terima kasih kepada Direktur Poltekkes Kemenkes Jakarta II yang telah memberikan dana Penelitian Terapan Unggulan melalui DIPA Poltekkes Kemenkes Jakarta II tahun anggaran 2019 melalui SK Direktur Poltekkes Kemenkes Jakarta II No. HK.02.03/I/3731/2019.

\section{DAFTAR PUSTAKA}

1. Jennifer H, Saptutyningsih E. Preferensi Individu Terhadap Pengobatan Tradisional di Indonesia. Jurnal Ekonomi dan Studi Pembangunan. 2015;16(April):26-41.

2. Nazri G, Lilianti E. Efektifitas Berkumur Rebusan Daun Sirih 10 \% Dibandingkan Obat Kumur Yang Mengandung Cetylpyridinium chloride Terhadap Penurunan Jumlah Bakteri Rongga Mulut. J PDGI. 2016;65(1):1-5.

3. Shahab MAA. Aktivitas Antibakteri Ekstrak Daun Sirih Hijau (Piper Betle L.) Terhadap Bakteri Patogen Dari Susu Segar. Institut Pertanian Bogor; 2016.

4. Anas R, Puspitasari Y. Perbedaan Daya Hambat Antibakteri Antara Ekstrak Daun Sirih Merah (Piper crocatum) Dan Ekstrak Daun Sirih Hijau (Piper betle L.) Terhadap Bakteri Streptococcus mutans. As-Syifaa. 2018;10(01).

5. Kursia S, Lebang JS, Taebe B, Burhan A, R Rahim WO. Uji Aktivitas Antibakteri Ekstrak Etilasetat Daun Sirih Hijau (Piper betle L.) terhadap Bakteri Staphylococcus epidermidis. IJPST. 2016;3(2).

6. Aulia Syahrinastiti T, Djamal A, Irawati L. Perbedaan Daya Hambat Ekstrak Daun Sirih Hijau ( Piper betle L. ) dan Daun Sirih Merah ( Piper crocatum Ruiz \& Pav ) terhadap Pertumbuhan Escherichia coli. Jurnal Kesehatan Andalas. 2015;4(2). 
7. Bustanussalam B, Apriasi D, Suhardi E, Jaenudin D. Efektivitas Antibakteri Ekstrak Daun Sirih (Piper betle Linn) Terhadap Staphylococcus aureus ATCC 25923. Fitofarmaka Jurnal Ilmu Farmasi. 2015;5(2).

8. Beta A, Dewi C, Himawanto DWIA, Masykuri M. Rendemen Tar Pirolisis Sampah Kota dengan Komposisi Organik / Anorganik ( 70 / 30 \% w / w ). J Ekosains. 2016;10(3):1-7.

9. Erawati E, Kirana TW, Budiyati E, Sediawan WB. Distilasi Asap Cair Hasil Pirolisis Limbah Serbuk Gergaji Kayu Glugu. In: Simposium Nasional RAPI XIV - 2015 FT UMS. 2015. p. 213-9.

10. Emalia Sukmawati A, Irwandi D. Pengembangan Sediaan Obat Kumur Berbahan Aktif Asap Cair Daun Sirih Hijau (Piper betle L). 2019.

11. Irwandi D, Emalia Sukmawati A, Ulfa DM. Chemical Compound Of Liquid Smoke Derived From Leaf Of Piper betle L And Piper crocatum Ruiz \& Pav. Sanitas Jurnal Teknologi Dan Seni Kesehatan. 2018;09:35-43.

12. Septi andini M. Parameter Utama Asap Cair Untuk Standar Nasional Indonesia. Institut Pertanian Bogor; 2015. 
